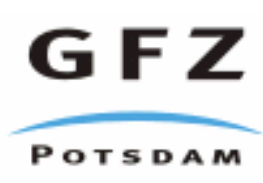

An edited version of this paper was published by AGU. Copyright 2004 American Geophysical Union.

TRANSALP Working Group First deep seismic reflection images of the Eastern Alps reveal giant crustal wedges and transcrustal ramps In: Geophysical Research Letters, 29, 102002.

DOI: $\underline{10.1029 / 2002 G L 014911}$ 


\title{
First deep seismic reflection images of the Eastern Alps reveal giant crustal wedges and transcrustal ramps
}

\author{
TRANSALP Working Group ${ }^{1}$ \\ Received 13 February 2002; revised 25 March 2002; accepted 8 April 2002; published 28 May 2002.
}

[1] The Alps are considered as a classical example for an orogen created by continental plate collision. In this study we present new images obtained from deep seismic reflection profiling in the Eastern Alps between Munich and Venice which give rise to examine and revise existing concepts. The seismic sections exhibit a prominent bi-verging reflection pattern at crustal scale. A major ramp-like structure, outcropping at the Inn-Valley fault, can be traced southward over $80 \mathrm{~km}$ into the mountain root where relics of the subducted Penninic ocean are expected. New models of the evolution of the Eastern Alps show an upper/lower crustal decoupling along transcrustal thrust faults with opposite thrust directions of both the European and the Adriatic-African continents. INDEX TERMS: 0905 Exploration Geophysics: Continental structures (8109, 8110); 0935 Exploration Geophysics: Seismic methods (3025); 8102 Tectonophysics: Continental contractional orogenic belts; 7205 Seismology: Continental crust (1242); 9335 Information Related to Geographic Region: Europe

\section{Introduction}

[2] The Eastern Alps result from the consumption of the small Penninic Ocean and the subsequent collision of the European plate with the Adriatic plate, an off-split from Africa. In early models based on plate tectonic principles a southward [Dewey and Bird, 1970; Laubscher, 1975; Hawkesworth et al., 1975] as well as northward [Oxburgh, 1972] subduction was suggested for the Alps. The interaction of the two plates was explained by crustal splitting, wedging and the detachment of flakes [Oxburgh, 1972]. More recently, the concept of a thin skinned wedge to the North (including the Northern Calcareous Alps, NCA), a thick skinned backthrust wedge to the South (including the Dolomite Mountains) and a core zone (Tauern Window) which was uplifted along a presumed transcrustal ramp was developed from field data [Lammerer and Weger, 1998; Castellarin and Cantelli, 2000]. Lateral escape to the East affected the central Eastern Alps [Ratschbacher et al., 1991; Frisch et al., 1998; Neubauer et al., 1999].

\footnotetext{
${ }^{1}$ Helmut Gebrande, Ewald Lüschen, Michael Bopp, Florian Bleibinhaus, Bernd Lammerer (University of Munich, Theresienstrasse 41, D-80333 Munich, Germany); Onno Oncken, Manfred Stiller, Jörn Kummerow, Rainer Kind (GeoForschungsZentrum Potsdam, Telegrafenberg, D-14473 Potsdam, Germany); Karl Millahn, Herfried Grassl (University of Leoben, Franz-Josef-Strasse 18, A-8700 Leoben, Austria); Franz Neubauer (University of Salzburg, Hellbrunner Strasse 43, A-5020 Salzburg, Austria); Luca Bertelli, Daniela Borrini, Roberto Fantoni, Camillo Pessina, Mattia Sella (ENI-AGIP Division, Via Emilia 1, I-20097 San Donato Milanese, Italy); Alberto Castellarin (University of Bologna, Via Zamboni 67, I-40127 Bologna, Italy); Rinaldo Nicolich (University of Trieste, Via Valerio 10, I-34127 Trieste, Italy); Alfredo Mazzotti (University of Milan, Via Cicognara 7, I-20129 Milano, Italy); Marcello Bernabini (University of Rome, Via Eudossiana 18, I-00184, Rome, Italy).
}

[3] The lack of seismic reflection data in the Eastern Alps was the motivation for TRANSALP which is a European multidisciplinary research programme for investigating orogenic processes by partner institutions from Italy, Austria and Germany [TRANSALP Working Group, 2001]. Seismic profiling forms the core of the study, which is accompanied by a number of specific geoscientific projects. Although the main data acquisition was divided into three different campaigns in 1998 and 1999, the project gathered for the first time a continuous, approx. $300 \mathrm{~km}$ long section covering the orogen at its broadest width as well as parts of the two adjacent Molasse basins (Figure 1). This long, continuous section allows imaging by modern depth migration, in contrast to most of the previous studies in the Western Alps [Roure et al., 1990; Pfiffner et al., 1997].

[4] In contrast to the Western Alps, vast areas of the Eastern Alps are covered by Austroalpine nappes consisting of Adriatic crystalline basement and carbonate shelf sediments of the former Adriatic active plate boundary. Only the narrow zone of the Tauern Window includes uplifted and largely outcropping medium- to high-grade metamorphic crystalline rocks of the European basement with folded granitic sills, paragneisses and amphibolites, surrounded by oceanic calc-micaschists and ophiolites comparable to the much broader Penninic zones in the Western Alps. South of the Tauern Window, the seismic line intersects the Periadriatic Fault (PF), a prominent dextral strike slip fault which is linked by the Giudicarie Fault (GF) to the Insubric Line further west (Figure 1). Post-collisional structural accretion along the $\mathrm{N}$ and $\mathrm{S}$ borders affected the whole Alps till $10 \mathrm{Ma}$. Only in the Venetian region compressional accretion occurred to the present [Castellarin and Cantelli, 2000].

\section{Data Acquisition and Processing}

[5] Seismic reflection data were acquired using the Vibroseis and the explosion technique during three field campaigns between autumn 1998 and autumn 1999 and a small complementary explosion experiment in summer 2001. The table lists the most important acquisition parameters. Shots were fired when the Vibroseis rolling spread arrived in both, North and South off-end configuration including the spare spread with up to 1100 channels. The seismic reflection profiling was accompanied by passive cross-line recording (7 cross lines of about $20 \mathrm{~km}$ length each) for 3-D control. Supplementary passive observations with a wide-spread 3-component stationary network listening all seismic sources in wide-angle configuration provided velocity control. Local and global earthquakes were recorded for more than 9 months by another network for lithospheric tomography and earthquake studies.

[6] During Vibroseis processing many versions have been produced on different software and hardware platforms at Munich and Leoben universities and at the AGIP company at Milan, ranging from conventional common-midpoint (CMP-)stacking and post-stack time and depth (Kirchhoff-) migration, applied on the whole section, to dip-moveout (DMO-)stacking and pre-stack depth migration applied on crucial sectors, all having their specific advantages for interpretation. Strongly crooked geometry and varying recording conditions required iterative improvement of processing parameters, in particular with respect to amplitude scaling (geometrical spreading correction and, optionally, automatic gain control AGC and trace equalisation), static corrections and velocity model building. A short-window (400 ms) AGC 
Table: TRANSALP Seismic Acquisition Parameters

\begin{tabular}{|c|c|}
\hline Parameter VIBROSEIS & Value \\
\hline $\begin{array}{l}\text { Configuration: length, } \\
\text { number of channels }\end{array}$ & Split Spread, 18 km, 360 \\
\hline Source & 4 Vibrators, total peak force $872 \mathrm{kN}$ \\
\hline $\begin{array}{l}\text { Sweep: frequencies, } \\
\text { length, stacks }\end{array}$ & $10-48 \mathrm{~Hz}, 28 \mathrm{~s}, 8$ \\
\hline $\begin{array}{l}\text { Geophone type, } \\
\text { No of geophones per group }\end{array}$ & $10 \mathrm{~Hz}, 12$ in-line \\
\hline $\begin{array}{l}\text { Geophone group spacing, } \\
\text { source spacing }\end{array}$ & $50 \mathrm{~m}, 100 \mathrm{~m}$ \\
\hline Correlated record length & $20 \mathrm{~s}$ \\
\hline Nominal CMP coverage & 90 \\
\hline Parameter DYNAMITE & Value \\
\hline Configuration spread length & Off-end, $20-50 \mathrm{~km}$ variable \\
\hline Source, source spacing & 3 holes à $30 \mathrm{~m}$ depth, $5 \mathrm{~km}$ average \\
\hline Explosive charge & $90 \mathrm{~kg}, 30 \mathrm{~kg}$ per hole \\
\hline Record length & $60 \mathrm{~s}$ \\
\hline Nominal CMP coverage & 2 \\
\hline
\end{tabular}

turned out to the most effective and robust one for increasing the signal-to-noise ratio during stacking. Static corrections (datum level $\mathrm{H} 800 \mathrm{~m}$ ) consisting of elevation statics, stripping of the upper $2-3 \mathrm{~km}$ according to a velocity model based upon inversion of the first arrivals, and subsequent automatic residual corrections, followed by iterative normal-moveout (NMO-)analysis, proved to be of crucial importance for signal enhancement. The velocity model required for depth migration was obtained by analysis of the stacking velocities in the layered structure of the Molasse areas and by tomographic inversion of the first arrivals of Vibroseis and explosive data recorded in the wide-aperture stationary network (offsets up to $80 \mathrm{~km}$ resulted in depth penetration to about $15 \mathrm{~km}$ ) in the Alpine areas. For the deeper parts a macro velocity model from older, but still compatible deep seismic refraction measurements [Miller et al., 1977] was used. The explosive seismic data were processed in a similar way in principle, except static corrections (only elevation statics) and NMO-analysis. Large source offsets and varying signal characteristics required to process them separately for imaging mainly the lower crust including the crustmantle boundary. Velocity models of the Vibroseis survey were used for NMO and migration. From the low-fold data only the good-quality seismic traces were selected to form a single-fold section which was then time- and depth-migrated.

\section{The New Seismic Sections and Their Interpretation}

[7] The interpretation of the TRANSALP data is based upon a variety of different versions at appropriate scales (1:50000, $1: 100000)$. A synoptic view on stack (zero-offset time), time and depth migrated sections is necessary to evaluate these sections because of well-known difficulties in migration of deep-crustal events. Despite of these problems which tend to produce 'smiles', both migration techniques were reasonably successfull. This is documented in the predominant criss-cross reflection pattern at $\mathrm{km}$ 175-200 in the Vibroseis stack section (Figure 2). After depth migration (similarly after time migration) the elements focus well and migrate to their position, as expected from the ray-theoretical point of view, and produce a bi-verging pattern at $\mathrm{km} 150-220$. On the contrary, lower crustal reflective spots and sectors, e.g., at km $130-140$ and about $16 \mathrm{~s}$, produce smiles because of their truncated character and smear out along the section.

[8] To the North the Vibroseis sections display about $80 \mathrm{~km}$ of the Bavarian Molasse showing the top of the Mesozoic as the most prominent reflectors. They can be traced towards the South underneath the nappes of the Northern Calcareous Alps (NCA), eventually including parautochthonous sediments, and even further to the crystalline Tauern Window. There are vertical 4-5 km dis- placements of the basal reflections beneath the Alpine front $(\mathrm{km} \mathrm{70})$ and beneath the Inn Valley (km 100). The Inn Valley is also the place of an outcropping prominent southward dipping reflection pattern. This indicates that the NCA continue to the South where they are overthrust by the Greywacke Zone (GWZ), their former basement. The NCA and the GWZ form the northern orogenic wedge over a width of 60 kilometres with north-verging structures throughout the section. South of the Tauern Window, there is a giant bi-verging pattern of subparallel reflections, mentioned above, extending from the surface to the crustal root at about $55 \mathrm{~km}$ depth. For some of these reflections a negative polarity has been proven, which is indicative for intercalated lowimpedance tectonized (wet, cataclastic, sheared) material. A particularly prominent pattern of southward dipping reflections crops out at the Inn Valley and extends to the orogenic root, referred as 'SubTauern-Ramp' in our models in Figure 3. The Periadriatic Fault (PF) cannot be clearly identified (see also discussion in TRANSALP Working Group, [2001]). The relatively shallow and subhorizontal layers of the Dolomite Mountains are accompanied by a reflective pattern in the first few kilometres of depth. Northward dipping reflections can be attributed to a system of backthrust faults referred as 'Sub-Dolomites Ramp'. Upper-crustal stratified seismic reflections reaching about $10-15 \mathrm{~km}$ depth characterise the southernmost sector of about $50 \mathrm{~km}$ length.

[9] The 'receiver functions' (Figure 2, lower part) particularly image the crust-mantle boundary ('Moho') by P-to-S wave conversions of teleseismic events. The coincidence with the explosive seismic reflections from the lower crust is surprisingly good, despite of the low lateral and vertical resolving power of the long wavelength $(20-30 \mathrm{~km})$ receiver functions. From the north to the central part of the section the base of the reflective lower crust can be followed with a slight dip from $30 \mathrm{~km}$ depth in the north to $55-60$ $\mathrm{km}$ depth beneath and south of the Tauern Window. This seismically pronounced lower crust is remarkably thinner than to the North of the Molasse basin where previous DEKORP seismic reflection data [Meissner and Bortfeld, 1990] detected a reflective interval between $15 \mathrm{~km}$ and $30 \mathrm{~km}$ depth beneath a relatively transparent upper crystalline crust. In the TRANSALP section the

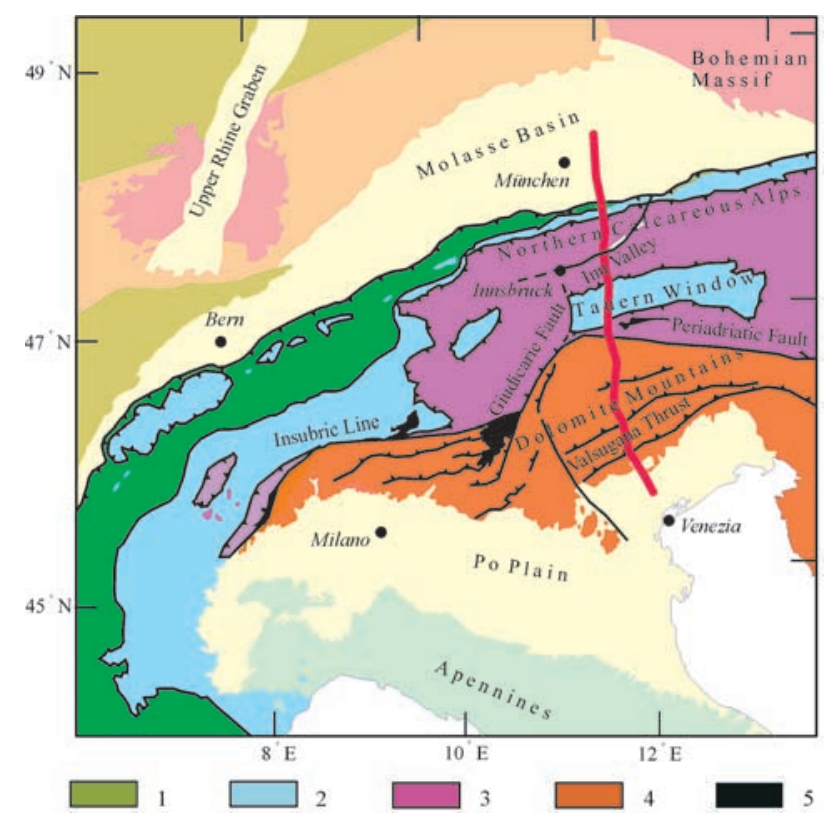

Figure 1. Simplified tectonic map of the Alps showing the location of the TRANSALP seismic section in the Eastern Alps. Length along seismic line is $340 \mathrm{~km}$. Alpine units: $1=$ Helvetic units, $2=$ Penninian units, $3=$ Austroalpine units, $4=$ Southern Alps, 5 = Periadriatic intrusions (paleogene). 

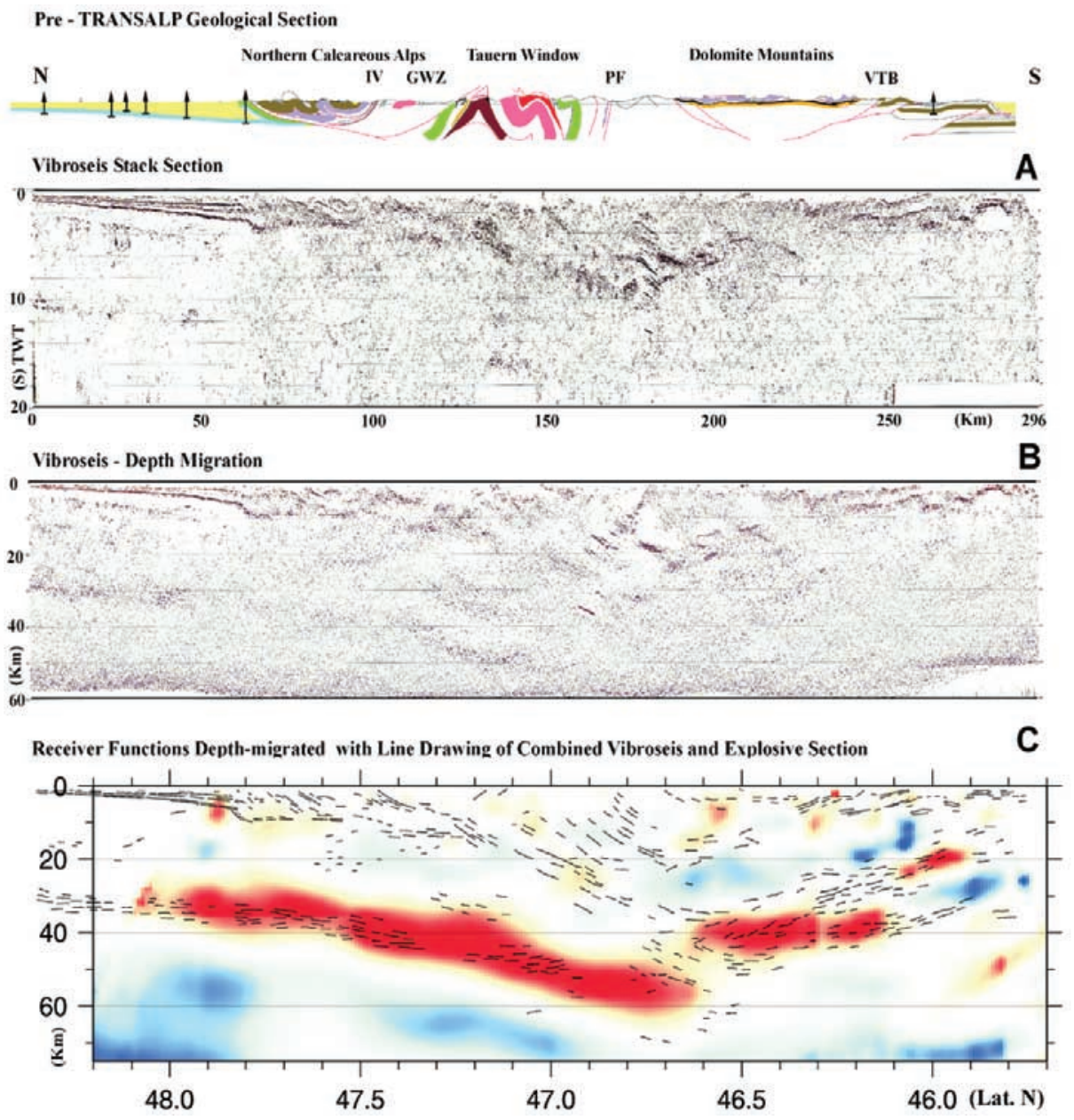

Figure 2. Seismic sections. On top: Geological near-surface profile derived from mapping; exploration drillholes are marked; (a) Vibroseis zero-offset time section after common-midpoint stacking; (b) Vibroseis depth-migrated section; (c) Depth-migrated receiver functions and simplified composite line drawing from Vibroseis and explosive sections superposed. The crust-mantle boundary ('Moho') as seen by the receiver functions corresponds to the maximum (in red) of P-to-S converted teleseismic signals. IV Inn Valley, GWZ Greywacke Zone, PF Periadriatic Fault, VTB Valsugana Thrust Belt.

top and bottom of the European crust are almost parallel and show a continuously increasing bending towards the Tauern Window. This indicates that the origin of the lower crustal reflectors is older than the Alpine orogeny. A pattern of reversed and steeper dip is visible on the Adriatic side of the section, subdivided vertically into two similar reflective zones with a total thickness of $25 \mathrm{~km}$ which is considerably larger than the lower crustal thickness on the European side. This thick (or double) lower crust, confirmed further south by high velocities determined by previous seismic refraction profiling [Scarascia and Cassinis, 1997], might be of pre-Alpine (Hercynian or older) age due to crustal stacking [Castellarin and Vai, 1981]. However, volcanism and marine sedimentation indicate thinning of the crust by extensional tectonics in Permo-Mesozoic times [ $\mathrm{Dal}$ Piaz, 1993]. In this case, the lower crust might also have been thickened by underplating (melting) of subducted continental and oceanic crust during the Alpine orogeny.

\section{Two Alternative Models}

[10] Figure 3 shows two alternative models which are presently in discussion. A common feature of both models is a major crustal shear zone acting as a ramp, dipping from the Inn valley southward ('Sub-Tauern Ramp', Figure 3) over 80 km into the mountain root. Because of exposed ophiolites and sediments of the subducted Penninic ocean around the Tauern Window we expect such remnants also at the deeper part of the ramp marking the former subduction zone. Model A ("Crocodile Model") considers the prominent reflectors as Alpine tectonic structures imaging shear zones of brittle or ductile character. According to this model, the edge of the initially cooler Tauern Window crust, supposed to represent the former European passive plate boundary, wedges deep $(\sim 50 \mathrm{~km})$ into the approaching Adriatic plate splitting-up its upper and lower crust at the level of the brittle/ductile transition and thereby displacing the Dolomite block to the South. Flexural slip surfaces might be responsible for the southward dipping subparallel reflections which may be further enhanced by intrusion of fluids from dewatering of sediments trapped at greater depths by closure of the Penninic ocean. The upper crust of the Adriatic plate north of the Dolomites was thrust as Austroalpine basement nappes, which carried the NCA over the Tauern Window by another 50 kilometers. With proceeding collision the Adriatic lower crust subsequently pushed the Tauern Window into its uplifted position. Consequently, the Dolomite Mountains block was backthrust to the South along the 'Sub-Dolomites Ramp' (Figure 3). The interface of the two colliding plates resembles a double "crocodile" structure. In model A the depth of the PF dextral strike slip fault is limited to the Dolomite Mountains block. This deviates from all former models and is also different from the Western Alps and implies that the PF does not directly correspond to the Insubric line of the Western Alps. 

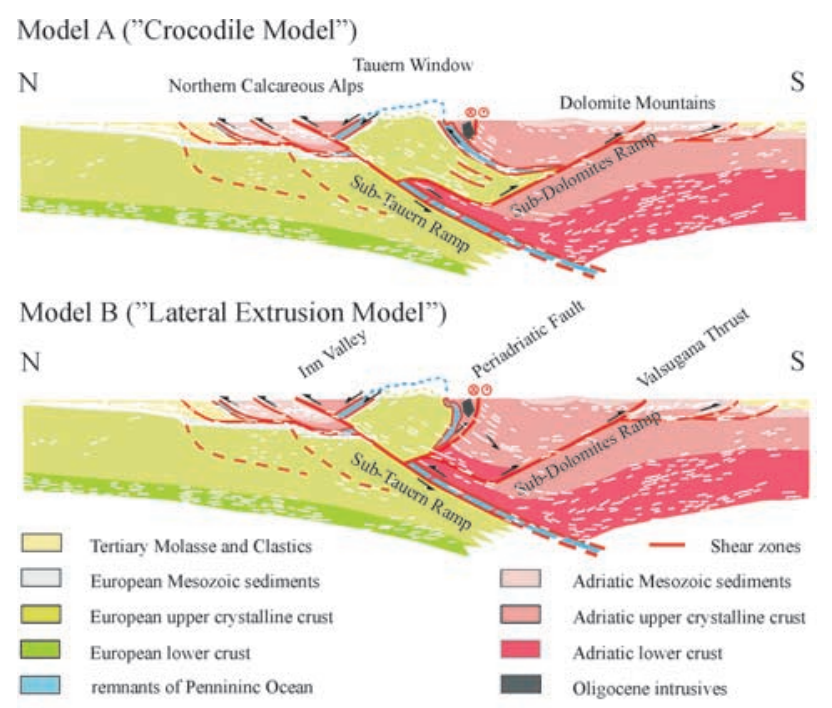

Length of section $300 \mathrm{~km} ; 1$ : 1

Figure 3. Interpretional cartoon showing two controversial models. Both models are widely identical except the lower part of the Tauern Window and adjacent parts south of it. European domains are marked in green colours, Adriatic-African domains in red colours, remnants of the Pennininc Ocean between them in blue. Simplified seismic reflections are superposed as manual line drawing. Geographic terms and marked fault zones apply for both models.

[11] Model B ("Lateral Extrusion Model") describes the Eastern Alps according to earlier views in an indenter-style similar to the Western Alps [Pfiffner et al., 1997]. In contrast to model A, it presumes that the steep northward dip of the PF observed near the surface continues to greater depth. It implies that there is no detectable impedance contrast across the PF. Instead, it separates a highly reflective upper and middle crust in the Southern Alps from a less reflective zone in the Tauern. The Dolomite sector of the Southern Alps is rheologically considered as a rigid block, consolidated by Early Permian, Mid Triassic and Paleogene intense intrusive and effusive magmatic activities, preventing a wedge indentation of the ductile Penninian units beneath the Southern Alps, and rather enforcing lateral extrusion of the Penninian. The model is supported by back folding and overturning of the Austroalpine belt along the southern border of the Tauern Window close to the PF.

[12] The bi-verging character of the Alpine architecture is evident from the seismic sections, including major ramps, along which giant crustal wedges have been upthrusted: the southward dipping 'Sub-Tauern Ramp' exposed at the Inn Valley, and the northward dipping 'Sub-Dolomites Ramp' which crops out in the Valsugana-Agordo area. Both areas exhibit recent tectonic activity as evidenced by shallow earthquakes delimiting the brittle upper crust. The Inn Valley activity is of mixed thrust-fault to strike-slip character, the Valsugana-Agordo one is of clear thrust type [Slejko et al., 1989]. These bi-verging conjugate shear zones at crustal scale, interpreted from the seismic sections, correspond well to mechanical and numerical modelling [Beaumont et al., 1996; Pfiffner et al., 2000]. In the N-S section of the Eastern Alps as imaged by TRANSALP only compressional structures are evident, whereas indications of any Alpine extensional tectonics within the orogenic wedge [Platt, 1986] are completely absent. The 'crocodile' model (A, Figure 3 ) focuses on the bi-verging character and provides a better solution for unravelling the present structure back to the beginning of the continental collision along a N-S section. In this context, the Periadriatic Fault looses its formerly presumed character of a first-order and deep reaching suture cutting the European and the Adriatic-African plates. The lateral extrusion model (B, Figure 3 ) is conservative and provides a better solution of the ductile extrusion of the Penninic units (Tauern Window). The two models coincide widely but are conceptionally different in their central part. The new seismic sections have already stimulated further research for additional refinement of our knowledge of the Alps.

[13] Acknowledgments. The TRANSALP programme is jointly financed by the Bundesministerium für Bildung und Forschung (BMBF, Bonn), the Bundesministerium für Wissenschaft und Verkehr (BMWV, Vienna), the Consiglio Nazionale delle Ricerche (CNR, Roma) and the company ENI-AGIP (Milan). We thank two anonymous reviewers for their helpful constructive comments.

\section{References}

Beaumont C., S. Ellis, J. Hamilton, and P. Fullsack, Mechanical model for subduction-collision tectonics of Alpine-type compressional orogens, Geology, 24, 675-678, 1996.

Castellarin A., and G. B. Vai, Importance of the Hercynian tectonics within the framework of the Southern Alps, Journal of Structural Geology, 3, 477-486, 1981

Castellarin A., and L. Cantelli, Neo-Alpine evolution of the Southern Eastern Alps, Journal of Geodynamics, 30, 251-274, 2000.

Dal Piaz G. V., Evolution of Austro-Alpine and Upper Penninic Basement in the Northwestern Alps from Variscan convergence to Post-Variscan extension, in Prae-Mesozoic Geology in the Alps, edited by J. F. von Raumer and F. Neubauer, pp. 328-343, Springer-Verlag, 1993.

Dewey J. F., and J. M. Bird, Mountain belts and new global tectonics, J. Geophys. Res., 75, 2625-2647, 1970.

Frisch W., J. Kuhlemann, I. Dunkl, and A. Brügel, Palinspastic reconstruction and topographic evolution of the Eastern Alps during late Tertiary tectonic extrusion, Tectonophysics, 297, 1-15, 1998.

Hawkesworth C. J., D. J. Waters, and M. J. Bickle, Plate tectonics in the Eastern Alps, Earth and Planetary Science Letters, 24, 405-413, 1975. Lammerer B., and M. Weger, Footwall uplift in an orogenic wedge: The Tauern Window in the Eastern Alps of Europe, Tectonophysics, 285, $213-230,1998$

Laubscher H. P., Plate boundaries and microplates in Alpine history, American Journal of Science, 275, 865-876, 1975.

Meissner R., and R.K. Bortfeld, (eds.), DEKORP-Atlas, Results of Deutsches Kontinentales Reflexionsseismisches Programm, SpringerVerlag, Berlin, 1990.

Miller H., H. Gebrande, and E. Schmedes, Ein verbessertes Strukturmodell für die Ostalpen, abgeleitet aus refraktionsseismischen Daten unter Ber̈̈cksichtigung des Alpen-Längsprofils, Geol. Rundschau, 66, 289308,1977

Neubauer F., J. Genser, W. Kurz, and X. Wang, Exhumation of the Tauern window, Eastern Alps, Phys. Chem. Earth Part A: Solid Earth and Geodesy, 24, 675-680, 1999.

Oxburgh E. R., Flake tectonics and continental collision, Nature, 239, $202-$ 204, 1972

Pfiffner O. A., P. Lehner, P. Heitzmann, St. Mueller, and A. Steck, (eds.), Results of NRP20 -Deep Structure of the Alps, Birkhäuser Verlag, Basel, 1997.

Pfiffner O. A., S. Ellis, and C. Beaumont, Collision tectonics in the Swiss Alps: Insight from geodynamic modelling, Tectonics, 19, 1065-1094, 2000.

Platt J. P., Dynamics of orogenic wedges and the uplift of high-pressure metamorphic rocks, Geol. Soc. Amer. Bull., 97, 1037-1053, 1986.

Ratschbacher L., W. Frisch, H. G. Linzer, and O. Merle, Lateral extrusion on the Eastern Alps, Part 2: Structural analysis, Tectonics, 10, 257-271, 1991.

Roure F., P. Heitzmann, and R. Polino, (eds.), Deep structure of the Alps, Mém. Soc. géol. Fr., 156; Mém. Soc. géol. suisse, 1; Vol. spec. Soc. Geol. It., 1, 350 p., 1990.

Scarascia S., and R. Cassinis, Crustal structures in the central-eastern Alpine sector: A revision of the available DSS data, Tectonophysics, 271, 157-188, 1997.

Slejko D., G. B. Carulli, R. Nicolich, A. Rebez, A. Zanferrari, A. Cavallin, C. Doglioni, F. Carraro, D. Castaldini, V. Iliceto, E. Semenza, and C. Zanolla, Seismotectonics of the eastern Southern Alps: A review, Boll. Geof. Teor: Appl., 31, 109-136, 1989.

TRANSALP Working Group, European orogenic processes research transects the Eastern Alps, EOS Trans, AGU, 82, 453, 460-461, 2001.

E. Lueschen, University of Munich, Geophysical Institute, Theresienstrasse 41, D-80333 Munich, Germany. (lueschen@geophysik. uni-muenchen.de) 